be insufficient to solve these difficulties. ${ }^{41}$ The recent introduction of protein A from Staphylococcus aureus ${ }^{42}$ may perhaps offer a new approach to this dilemma. This protein specifically forms insoluble complexes with $\gamma$-globulins and, hence, with most immune complexes and thereby allows the recovery of immune complexes from dilute solutions. Purified protein $A$ as well as protein A covalently bound to Sepharose beads may be purchased from Pharmacia Fine Chemicals AB (Bos 175, S-751 O4 Uppsala 1, Sweden).

Note added in proof: The application of protein A to immunoprecipitation of traces of membrane proteins is described in M. Maccechini, Y. Rudin, G. Blobel, and G. Schatz, Proc. Natl. Acad. Sci. USA. 76, (January) (1979).

${ }^{42}$ T. Kristiansen, Biochim. Biophys. Acta 263, 567 (1974); see also "Protein A- Protein A Sepharose CL-4B." Pharmacia Fine Chemicals Report November 1975-1.

\title{
[5] Biogenesis of Mitochondrial Membrane Proteins in Neurospora crassa
}

\author{
By Walter Sebald, Sigurd Werner, and Hanns Weiss
}

The biogenesis of enzyme complexes of the mitochondrial inner membrane, such as cytochrome oxidase, cytochrome $b c_{1}$, and ATPase, depends on a close cooperation of mitochondrial and cytoplasmic protein synthesis. Of the numerous polypeptide subunits which are present in these enzymes, some are synthesized on mitochondrial ribosomes and some on cytoplasmic ribosomes. In Neurospora crassa, both the assembly and the site of synthesis of these subunit polypeptides have been studied by in vivo incorporation of radioactive amino acids. (1) Pulse-labeling experiments with exponentially growing cells lead to the detection and identification of free subunits occurring as intermediates in the assembly of the functional enzyme complexes. ${ }^{1,2}$ (2) Incorporation of amino acids in the presence of specific inhibitors of mitochondrial or cytoplasmic ribosomes allowed the identification of the translational origin of the individual subunit polypeptides. ${ }^{3-6}$

\footnotetext{
${ }^{1}$ A. J. Schwab, W. Sebald, and H. Weiss, Eur. J. Biochem. 30, 511 (1972).

2 S. Werner, Eur. J. Biochem. 43, 39 (1974).

${ }^{3}$ H. Weiss, W. Sebald, and T. Bücher, Eur. J. Biochem. 22, 19 (1971).

${ }^{4}$ W. Sebald, W. Machleidt, and J. Otto, Eur. J. Biochem. 38, 311 (1973).

${ }^{5}$ H. Weiss and B. Ziganke, Eur. J. Biochem. 41, 63 (1974).

${ }^{6}$ G. Jackl and W. Sebald, Eur. J. Biochem. 54, 97 (1975).
} 
Pulse-Labeling of Proteins by in Vivo Incorporation of

Radioactive Leucine

Principle. Exponentially growing cells of the fungus Neurospora crassa are well suited for the pulse-labeling of polypeptides, ${ }^{1}$ as demonstrated in Fig. 1. Small amounts of leucine of defined specific radioactivity can be added directly to the growing cells. A minimal medium is used for growth; therefore, the radioactive amino acid is not diluted by the culture medium and is rapidly taken up by the cells. The intracellular leucine ( 2 to 4 $\mu$ mole/g of cellular protein) which serves as a precursor pool for protein synthesis, is turned over every 1 to 2 min by rapidly growing cells (doubling time of cell mass: 2 to $4 \mathrm{hr}$ ). Reutilization of leucine due to protein breakdown is not observed during exponential growth. ${ }^{1}$

Thus, a pulse-labeling of polypeptides is obtained when radioactive leucine is added in amounts comparable to the intracellular leucine pool. Cells can be harvested within $10 \mathrm{sec}$. This allows the measurement of labeling kinetics in the time intervals of $1 \mathrm{~min}$ and less. Labeling of total cellular protein is complete after 5 to $10 \mathrm{~min}$.

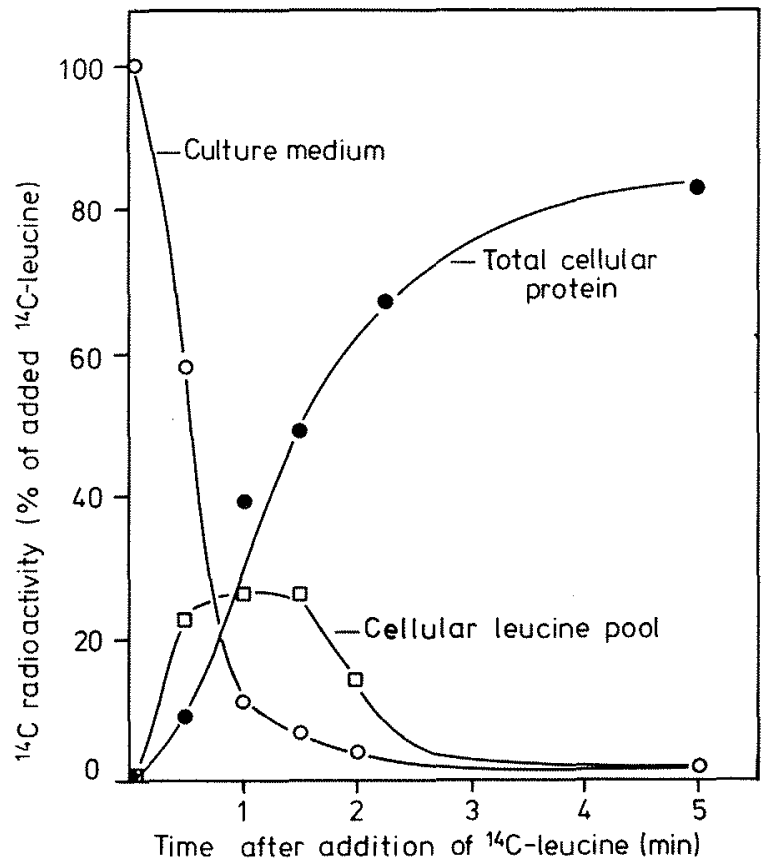

FiG. 1. Pulse-labeling of cellular proteins by addition of ${ }^{14} \mathrm{C}$-leucine to the culture medium. Time course of radioactivity in the culture medium $(0-0)$, in the cellular free leucine pool $(\square-\square)$, and in the total cellular protein (acid-insoluble radioactivity) $(\bullet-\bullet){ }^{1}$ 
Homogeneous Labeling of Polypeptides. It can be anticipated that the synthetic rate of a given polypeptide is proportional to its cellular content, since a constant protein pattern is maintained during exponential growth. At a certain time after addition of radioactive leucine, all proteins are labeled according to their individual leucine contents. ${ }^{4}$ The time period required for a so-called homogeneous protein labeling amounts to $60-120$ min in the case of cytochrome oxidase, ${ }^{1}$ cytochrome $b,{ }^{5}$ and the ATPase complex. ${ }^{7}$ After this time all pulse-labeled polypeptides have been integrated into the end-products, i.e., the functional enzyme complexes (see next section).

After a homogeneous labeling, the specific radioactivity of the total cell protein can be calculated.

$$
\mathrm{dpm} / \mathrm{mg} \text { protein }=\frac{\mathrm{dpm} \text { (leucine) added to the culture }}{\mathrm{mg} \text { protein per culture }}
$$

The specific radioactivities of individual proteins are similar to the average value and depend on the individual leucine contents.

With a single culture a double-labeling experiment can be performed as described in the following sections, First, proteins are labeled homogeneously by incorporation of ${ }^{14} \mathrm{C}$-leucine. The ${ }^{14} \mathrm{C}$-radioactivity serves as a control label. Subsequently, ${ }^{3} \mathrm{H}$-leucine is incorporated under special conditions.

Labeling Kinetics. LABELING PROCEDURE. ${ }^{14} \mathrm{C}$-Leucine is added to a culture of exponentially growing cells. ${ }^{8}$ After $2-3 \mathrm{hr}$ the ${ }^{14} \mathrm{C}$ label has been incorporated homogeneously into cellular proteins and can be used as a control label. The addition of 0.1 to $0.2 \mathrm{mCi}{ }^{14} \mathrm{C}$-leucine per gram of total cellular protein results in a sufficiently high specific radioactivity. Subsequently, ${ }^{3} \mathrm{H}$-leucine is added ( 1 to $5 \mathrm{mCi} / \mathrm{g}$ total cellular protein). At distinct intervals (see Figs. 2 and 3) samples are taken from the culture. For the preparation of functional cytochrome oxidase, aliquots of 1 liter corresponding to about $0.5 \mathrm{~g}$ total cellular protein are necessary. ${ }^{1}$ For immunological isolation procedures aliquots of 50 to $100 \mathrm{ml}$ corresponding to 25 to $50 \mathrm{mg}$ are sufficient. ${ }^{2}$ The cells are harvested by filtration and frozen immediately.

LABELING KINETICS OF SUBUNITS OF CYTOCHROME OXIDASE (END Products). Functional cytochrome oxidase is isolated from submitochondrial particles by means of chromatography on oleyl-methacrylic acid resin. ${ }^{3,9}$ The yield is 100 to $200 \mu \mathrm{g}$ enzyme per $10 \mathrm{mg}$ membrane protein. The cytochrome oxidase subunits are separated by sodium dodecyl sulfate-gel electrophoresis. ${ }^{4}$

\footnotetext{
${ }^{7}$ W. Sebald, Biochim. Biophys. Acta 463, 1 (1977).

${ }^{8}$ This series, Vol. 55 [18].

${ }^{9}$ This series, Vol. 53 [11].
} 


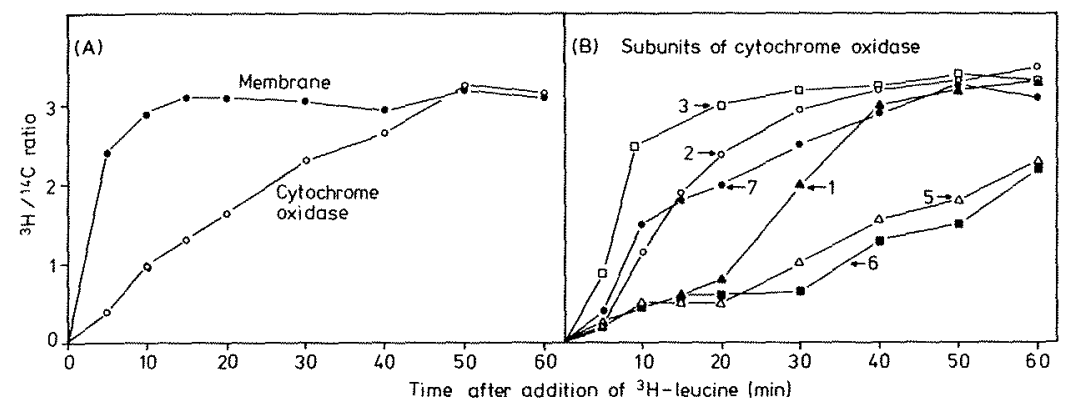

FIG. 2. Time course of labeling of (A) the total mitochondrial membrane protein and cytochrome oxidase and (B) of subunit polypeptides of cytochrome oxidase. ${ }^{3} \mathrm{H}$-Leucine was added $200 \mathrm{~min}$ after addition of ${ }^{14} \mathrm{C}$-leucine. ${ }^{1}$ The subunits are numbered according to Sebald et al. ${ }^{4.9}$

The whole membrane protein is labeled half-maximally after about 3 min, similar to the total cellular protein (Fig. $2 \mathrm{~A}$ ). The maximal ${ }^{3} \mathrm{H} /{ }^{14} \mathrm{C}$ ratio obtained corresponds to the ratio of ${ }^{3} \mathrm{H}$ and ${ }^{14} \mathrm{C}$ radioactivity added initially to the culture. The time course of the labeling of the whole cytochrome oxidase protein is delayed. After 50 to $60 \mathrm{~min}$, however, the same specific radioactivity $\left({ }^{3} \mathrm{H} /{ }^{14} \mathrm{C}\right.$ ratio) as in whole membrane protein is obtained. The labeling of each of the subunit polypeptides of cytochrome oxidase follows a different time course (Fig. 2B).

These results indicate that cytochrome oxidase is assembled from pools of free subunits. In the event that only one pool exists for a given

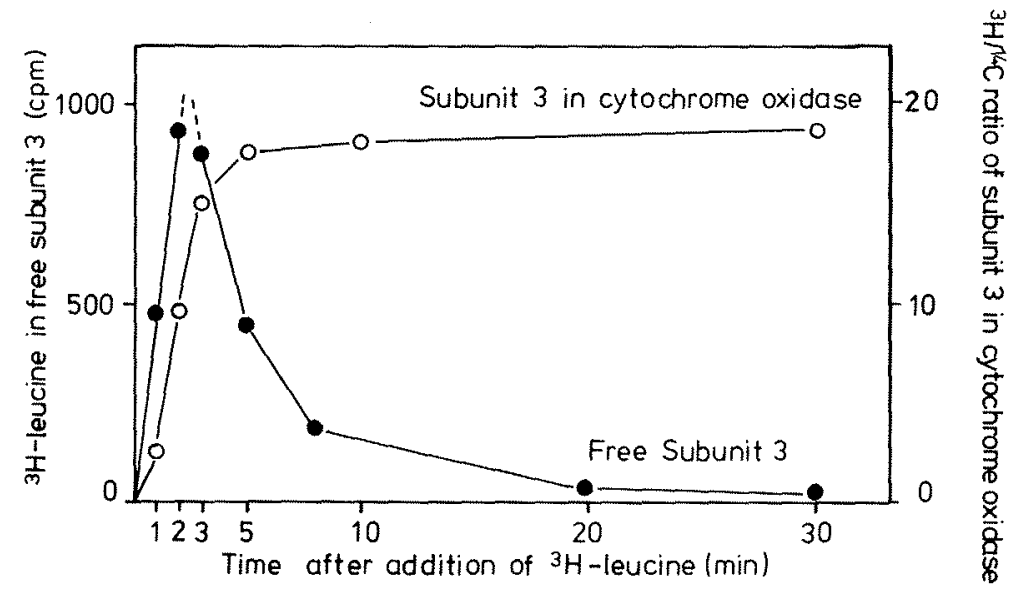

FIG. 3. Time course of labeling of free subunit $3(-)$ and subunit 3 integrated into cytochrome oxidase $(\mathrm{O}-\mathrm{O}) .{ }^{3} \mathrm{H}$-leucine was added $180 \mathrm{~min}$ after addition of the ${ }^{14} \mathrm{C}$-leucine. ${ }^{2}$ 
subunit, the half-life of that free subunit can be estimated by the following differences in the times needed for half-maximal labeling of whole membrane protein and subunit ${ }^{1}$ :

$t_{1 / 2}($ free subunit $)=t_{1 / 2}$ (subunit $)-t_{1 / 2}$ (membrane protein $)$

LABELING KINETICS OF A FREE SUBUNIT (INTERMEDIATE PRODUCT). The double-labeled mitochondria (see above) are dissolved by Triton $\mathrm{X}-100$. The supernatant is incubated with immunoglobulin specific for isolated subunit 3 (21,000 dalton) of cytochrome oxidase. The free subunit is quantitatively precipitated by means of a doubleimmunoprecipitation technique. ${ }^{3}$ (The specific isolation of the free subunit is possible, since the subunit integrated into the functional enzyme is no longer recognized by the immunoglobulin.) Aliquots of the immunoprecipitates are submitted to sodium dodecyl sulfate-gel electrophoresis. Radioactivity is determined in those peak fractions which correspond to the 21,000 dalton polypeptide.

As shown in Fig. 3, labeling of free subunit 3 is maximal after 2 to 3 min and then declines to negligible values within $20 \mathrm{~min}$. Over the entire period, no ${ }^{14} \mathrm{C}$ control label can be detected in the immunoprecipitates. For comparison, the time course of labeling of subunit 3 present in cytochrome oxidase is included in the figure. Cytochrome oxidase has been precipitated from Triton X-100-solubilized mitochondria with an antiserum to the whole enzyme." (The antiserum to cytochrome oxidase does not recognize the free subunit 3.) Subunit 3 in the immunoprecipitated cytochrome oxidase contains a constant ${ }^{14} \mathrm{C}$ control label. The ${ }^{3} \mathrm{H}-$ leucine label of this polypeptide increases continuously and reaches a maximum within $5 \mathrm{~min}$. (The labeling in this experiment is more rapid than in the experiment shown in Fig. $2 B$ due to different growth rates of the cells.)

From the kinetic data it has been concluded that the free subunit is a genuine precursor of subunit 3 of cytochrome oxidase. ${ }^{2}$

\section{In Vivo Incorporation of Radioactive Leucine after Inhibition of Mitochondrial or Cytoplasmic Protein Synthesis}

Principle. In Neurospora crassa as in other eukaryotic cells, cycloheximide inhibits specifically the cytoplasmic $80 \mathrm{~S}$ type of ribosomes, ${ }^{10}$ whereas the mitochondrial $70 \mathrm{~S}$ type of ribosomes are inhibited specifically by chloramphenicol. ${ }^{11.12}$ In vivo incorporation of radioactive amino

${ }^{10}$ W. Sebald, A. J. Schwab, and T. Bücher, FEBS Lett. 4, 243 (1969).

$"$ W. Sebald, T. Bücher, B. Olbrich, and F. Kaudwitz, FEBS Lett. 1, 235 (1968).

${ }^{12}$ W. Sebald, H. Weiss, and G. Jackl, Eur. J. Biochem. 30, 413 (1972). 
acids in the presence of inhibitor results in the selective labeling of mitochondrially or cytoplasmically synthesized polypeptides, respectively. Chloramphenicol as well as cycloheximide inhibit the assembly of cytochrome oxidase ${ }^{4,12}$ and ATPase complex, ${ }^{6,7}$ which contain subunits of both cytoplasmic and mitochondrial origin. Thus, in the presence of either inhibitor, primarily free or partially assembled subunits are labeled. These labeled polypeptides can be integrated into the functional enzymes in vivo by special techniques.

Procedures for Amino Acid Incorporation. Throughout the experiments described, cultures are used in which cellular proteins are prelabeled homogeneously with ${ }^{14} \mathrm{C}$-leucine $(0.1$ to $0.2 \mathrm{mCi} / \mathrm{g}$ total cellular protein).

CYCLOHEXIMIDE. A 2-min preincubation of the cells with $0.1 \mathrm{mg}$ cycloheximide per milliliter of culture medium is sufficient for a more than 99\% inhibition of cytoplasmic protein synthesis. This means, the process, which consumes the main portion of cellular leucine, is blocked. Consequently, in the presence of cycloheximide only a few percent of the added tracer amino acid can be used up for mitochondrial protein synthesis, and the addition of low amounts of radioactive leucine does not result in a pulse-labelling.

Three procedures were used for a specific labeling of mitochondrially made polypeptides:

a. ${ }^{3} \mathrm{H}$-Leucine is incorporated for $60 \mathrm{~min}$ in the presence of cycloheximide.

b. Cells are first incubated with $4 \mathrm{mg}$ chloramphenicol per milliliter. Thereafter, the chloramphenicol is removed and ${ }^{3} \mathrm{H}$-leucine is incorporated for $60 \mathrm{~min}$ in the presence of cycloheximide.

c. Same as b, but 2 min after the ${ }^{3} \mathrm{H}$-leucine a chase of cold leucine ( 2 to $5 \mathrm{mM}$ ) is added.

${ }^{3} \mathrm{H}$-Leucine (high specific radioactivity) added in amounts of $1 \mathrm{mCi}$ per gram of total cellular protein results in a cycloheximide-resistant labeling (procedure a) of whole mitochondrial protein of $1 \times 10^{5}$ to $2 \times 10^{5}$ $\mathrm{dpm} / \mathrm{mg}$ protein. The cycloheximide-resistant labeling of whole mitochondrial protein is found to be increased to about $50 \%$ after the transitory incubation with chloramphenicol ${ }^{4}$ (procedure b). Stimulation is maximal after 15-30 min chloramphenicol preincubation. The labeling in the pulse-chase experiment (procedure c) is 5-10\% of the labeling without chase. ${ }^{6}$ After labeling, cells are harvested by filtration and washed with water, and mitochondria are isolated ${ }^{8}$ The labeled polypeptides are analyzed by sodium dodecyl sulfate-gel electrophoresis of whole mitochondrial protein as shown in Fig. 4. The cycloheximide-resistant ${ }^{3} \mathrm{H}$ label shows a similar distribution after each of the three labeling procedures. 


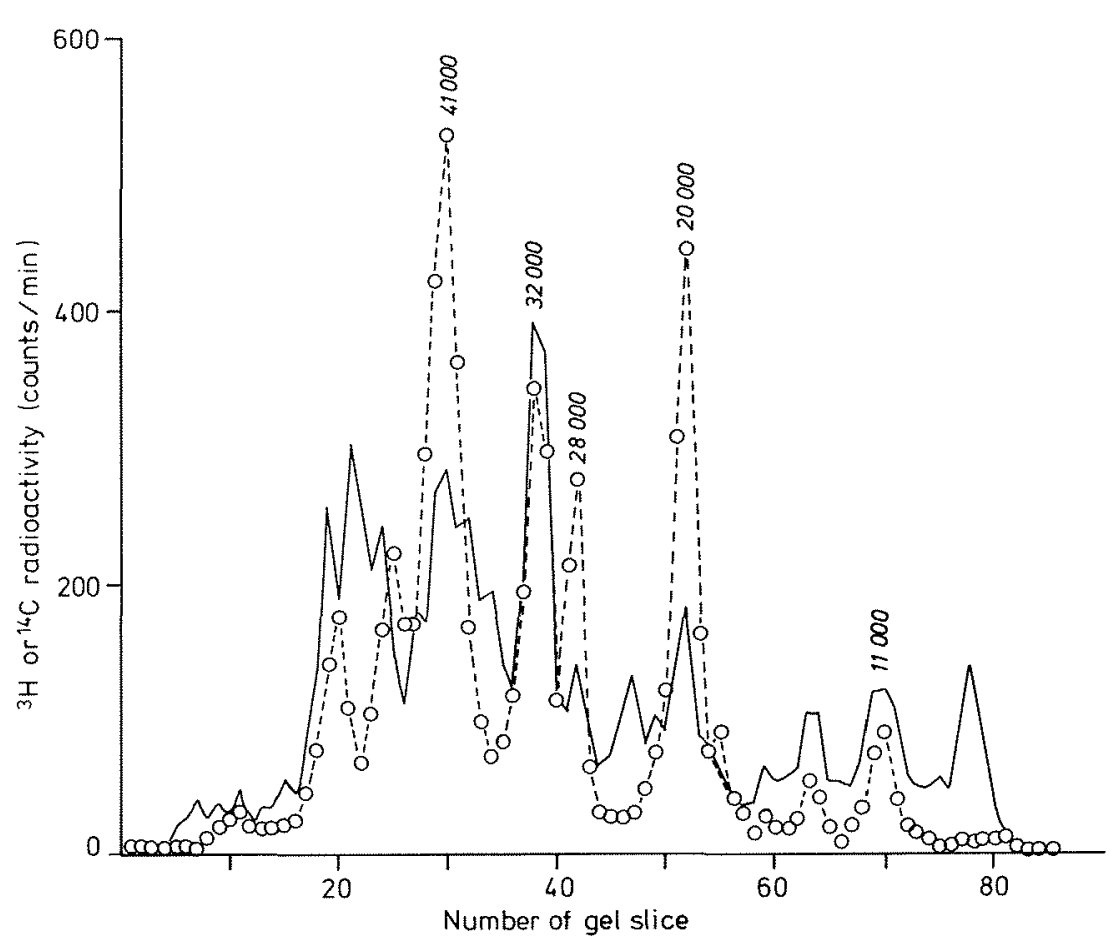

FrG. 4. Gel electrophoretic analysis of mitochondrially synthesized polypeptides. Distribution of $(\mathrm{O}-\mathrm{O})$ cycloheximide-resistant ${ }^{3} \mathrm{H}$-leucine label and $(-)$ homogeneous ${ }^{14} \mathrm{C}$ leucine label after sodium dodecyl sulfate-gel electrophoresis of whole mitochondrial protein.

Mitochondrially synthesized polypeptides are detected with molecular weights ranging from 11,000 to 60,000 daltons. Polypeptides of molecular weights $41,000,32,000,28,000,21,000,19,000$, and 11,000 have been correlated with subunits of cytochrome oxidase,,$^{3,4}$ cytochrome $b,{ }^{5}$ and the ATPase complex ${ }^{6}$ (see Table I). The labeling of the mitochondrially made subunits of the isolated enzyme complexes depends on the labeling procedure (Table I). The polypeptides which are synthesized and labeled in the presence of cycloheximide appear to a higher proportion in the isolated enzyme complexes after the transitory incubation of the cells with chloramphenicol. After a pulse-chase labeling, the specific cycloheximide-resistant radioactivity is found to be enriched still further. The specific radioactivity of cytoplasmically made proteins $(100,000 \mathrm{~g}$ supernatant) amounts to only $1-2 \%$ of that of the mitochondrially made polypeptides. 
TABLE I

ENRICHMENT OF CYCLOHEXIMIDE-RESISTANT LABEL IN SUbUNIT Polypeptides of Cytochrome Oxidase, Cytochrome $b$, and ATPase Complex Obtained after Different Labeling Procedures"

\begin{tabular}{|c|c|c|c|}
\hline \multirow[b]{4}{*}{ Protein fractions } & \multicolumn{3}{|c|}{$\begin{array}{l}\text { Relative specific radioactivities }{ }^{b} \\
\left({ }^{3} \mathrm{H} /{ }^{14} \mathrm{C} \text { ratios) after labeling in }\right. \\
\text { the presence of cycloheximide for }\end{array}$} \\
\hline & \multirow{3}{*}{$\begin{array}{l}60 \min \\
\text { (a) }\end{array}$} & \multicolumn{2}{|c|}{$\begin{array}{c}2 \mathrm{~min} \text { followed } \\
60 \mathrm{~min} \quad \text { by a } 60 \text {-min chase }\end{array}$} \\
\hline & & \multicolumn{2}{|c|}{$\begin{array}{l}\text { After a transitory incubation } \\
\text { with chloramphenicol }\end{array}$} \\
\hline & & (b) & (c) \\
\hline $\begin{array}{l}\text { Whole mitochondrial } \\
\text { membrane protein }\end{array}$ & 1 & 1 & 1 \\
\hline $\begin{array}{l}\text { Cytoplasmic protein } \\
(100,000 \mathrm{~g} \text { supernatant })\end{array}$ & 0.05 & 0.05 & 0.04 \\
\hline \multicolumn{4}{|l|}{$\begin{array}{l}\text { Mitochondrially made } \\
\text { subunits }\end{array}$} \\
\hline \multicolumn{4}{|l|}{ Cytochrome oxidase } \\
\hline $41,000 \mathrm{M}_{\mathrm{r}}$ & 0.34 & 1.75 & \\
\hline $28,000 \mathrm{M}_{\mathrm{r}}$ & 1.45 & 1.85 & \\
\hline $21,000 \mathrm{M}_{\mathrm{r}}$ & 3.55 & 3.55 & \\
\hline \multicolumn{4}{|l|}{ Cytochrome $b$} \\
\hline $32,000 \mathrm{M}_{\mathrm{r}}$ & 2.4 & & \\
\hline \multicolumn{4}{|l|}{ ATPase complex" } \\
\hline $19,000 \mathrm{M}_{\mathrm{r}}$ & 0.7 & 2.4 & 3.8 \\
\hline $11,000 \mathrm{M}_{\mathrm{r}}$ & 0.5 & 1 & 2 \\
\hline
\end{tabular}

"Proteins were labeled by the procedures $a, b$, and $c$ described in the text. The apparent molecular weights $\left(\mathrm{M}_{\mathrm{r}}\right)$ were determined by sodium dodecyl sulfate-gel electrophoresis.

${ }^{b}$ The specific radioactivities $\left({ }^{3} \mathrm{H} /{ }^{14} \mathrm{C}\right.$ ratios) are related to the ${ }^{3} \mathrm{H} /{ }^{14} \mathrm{C}$ ratio of whole mitochondrial protein.

Chloramphenicol. A 5-min preincubation of the cells with $4 \mathrm{mg}$ chloramphenicol per milliliter of culture medium results in a $80-90 \%$ inhibition of mitochondrial protein synthesis. ${ }^{6,12}$ Cytoplasmically made polypeptides are pulse-labeled by the addition of low amounts of radioactive leucine as in untreated cells, since the main path of cellular protein synthesis is not affected, at least in these short-term experiments.

Two labeling procedures were used:

1. ${ }^{3} \mathrm{H}$-Leucine is incorporated for $30 \mathrm{~min}$ in the presence of chloramphenicol. 
2. Same as 1 , but the chloramphenicol is removed after the labeling period, and the cells are grown for another 1 to $2 \mathrm{hr}$ in the absence of inhibitor.

Procedure 1 leads to the labeling of cytoplasmically made subunits of cytochrome oxidase and the ATPase complex which are not integrated into the functional enzymes when mitochondrial protein synthesis is inhibited. $^{6.12}$ Procedure 2 allows an integration of the accumulated labeled polypeptides into the enzyme complexes when the inhibitor is removed and normal growth is restored. The labeling of the mitochondrial translation products remains inhibited to $80-90 \%$ under both conditions.

\title{
[6] Analysis of Products of Mitochondrial Protein Synthesis in Yeast: Genetic and Biochemical Aspects
}

\author{
By M. Douglas, D. Finkelstein, and R. A. Butow
}

Recent developments in the genetics of yeast mitochondrial translation products have been made possible primarily as a result of less severe mutagenesis of the mitochondrial genome. ${ }^{1}$ Additionally, in vivo labeling and resolution methods have made possible either the detection of missing translation products in appropriate mutants ${ }^{2}$ or variant polypeptide species in the mitochondrial translation profile of otherwise wild-type strains. $^{3,4}$ The detection of these mitoribosome-translated species requires, in addition to high resolution on gels, relatively convenient and economical methods for examination of these peptides from a large sample number to (a) screen mutants and (b) perform segregation, recombination, and deletion mapping analyses. ${ }^{4}$

The protocol outlined here takes advantage of the fact that in vivo incorporation of ${ }^{35} \mathrm{SO}_{4}{ }^{2-}$ in the presence of cycloheximide labels specifically mitochondrial translation products. Furthermore, one can conveniently grow, label, and autoradiographically examine up to 100 strains or mutants at once. Also, the highly resolving gradient slab gels described here may be used as the second dimension in conjunction with an isoelectric focusing first dimension to further define mitochondrial translation

${ }^{1}$ A. Tzagoloff, A. Akai, and R. Needleman, J. Bacteriol. 122, 826 (1975).

${ }^{2}$ A. Tzagoloff, A. Akai, R. Needleman, and G. Zulch, J. Biol. Chem. 250, 8236 (1976).

${ }_{3}^{3}$ M. Douglas and R. Butow, Proc. Natl. Acad. Sci. U.S.A. 73, 1083 (1976).

${ }^{4}$ M. Douglas, E. Kendrick, P. Boulikas, P. Perlman, and R. Butow, in "The Genetic Function of Mitochondrial DNA" (C. Saccone and A. Kroon, eds.), p. 199. North-Holland Publ., Amsterdam, 1976. 